\title{
MULTI-CRITERIA ANALYSIS OF SYNTHESIS METHODS FOR Ni-BASED CATALYSTS
}

\author{
VEČKRITERIJSKA ANALIZA SINTEZNIH METOD NA OSNOVI Ni \\ KATALIZATORJA
}

\author{
Vesna Nikolić1, Boris Agarski² ${ }^{2}$ Željko Kamberovićc ${ }^{3}$, Zoran Anđićc ${ }^{4}$, Igor Budak², \\ Borut Kosec $^{5}$ \\ ${ }^{1}$ University of Belgrade, Innovation Center of the Faculty of Technology and Metallurgy, 4 Karnegijeva Street, 11120 Belgrade, Serbia \\ ${ }^{2}$ University of Novi Sad, Faculty of Technical Sciences, 6 Trg Dositeja Obradovića Street, 21000 Novi Sad, Serbia \\ ${ }^{3}$ University of Belgrade, Faculty of Technology and Metallurgy, 4 Karnegijeva Street, 11120 Belgrade, Serbia \\ ${ }^{4}$ University of Belgrade, Innovation Center of the Faculty of Chemistry, 12-16 Studentski Trg Street, 11000 Belgrade, Serbia \\ ${ }^{5}$ University of Ljubljana, Faculty of Natural Sciences and Engineering, 12 Aškerčeva Street, 1000 Ljubljana, Slovenia \\ vnikolic@tmf.bg.ac.rs
}

Prejem rokopisa - received: 2015-06-30; sprejem za objavo - accepted for publication: 2015-07-28

doi: $10.17222 / \mathrm{mit} .2015 .147$

Catalysts based on the $\mathrm{Ni} / \mathrm{Al}_{2} \mathrm{O}_{3}$ system are used in a variety of catalytic processes. Catalysts are commonly synthesized through thermochemical routes (impregnation, precipitation, coprecipitation and others). The authors prepared a $\mathrm{Ni}-\mathrm{Pd} / \mathrm{Al}_{2} \mathrm{O}_{3}$ catalyst supported by a ceramic foam, using a novel method, whereby the foam was impregnated with aerosol. This paper evaluates the synthesis methods for the experimentally obtained $\mathrm{Ni}-\mathrm{Pd} / \mathrm{Al}_{2} \mathrm{O}_{3}$ catalyst in comparison with other Ni-based catalysts, using three multi-criteria analysis methods (SAW, TOPSIS and PROMETHEE II). The synthesis methods for Ni-based catalysts were compared with respect to the following parameters: preparation method, addition of the precipitation agent during preparation, forming and mixing precursors, filtration, drying procedure, calcination, reduction, and the presence of $\mathrm{NiAl}_{2} \mathrm{O}_{4}$. The final results indicate that the synthesis method for the $\mathrm{Ni}-\mathrm{Pd} / \mathrm{Al}_{2} \mathrm{O}_{3}$ catalyst is the best ranked in comparison with the others.

Keywords: catalysts, multi-criteria analysis, $\mathrm{Ni}-\mathrm{Pd} / \mathrm{Al}_{2} \mathrm{O}_{3}$, ceramic foam, aerosol method

Katalizatorji na osnovi sistema $\mathrm{Ni} / \mathrm{Al}_{2} \mathrm{O}_{3}$ se uporabljajo v številnih katalitičnih procesih. Katalizatorji so običajno sintetizirani po termokemijski poti (impregancija, izločanje, koprecipitacija in drugi). Avtorji so pripravili Ni-Pd/ $\mathrm{Al}_{2} \mathrm{O}_{3} \mathrm{katalizator}$, podprt $\mathrm{s}$ keramično peno $\mathrm{z}$ uporabo nove metode, kjer je bila pena impregnirana $\mathrm{z}$ aerosolom. Članek ocenjuje sintezne metode eksperimentalno dobljenega Ni-Pd/ $\mathrm{Al}_{2} \mathrm{O}_{3}$ katalizatorja $\mathrm{z}$ drugimi katalizatorji na osnovi $\mathrm{Ni}, \mathrm{z}$ uporabo treh večkriterijskih analiznih metod (SAW, TOPSIS, and PROMETHEE II). Sintezne metode katalizatorjev na osnovi Ni, so bile primerjane po naslednjih parametrih: metoda priprave, dodatek izločevalnega sredstva med pripravo, oblikovanje in mešanje prekurzorjev, filtracija, postopek sušenja, kalcinacija, redukcija in prisotnost $\mathrm{NiAl}_{2} \mathrm{O}_{4}$. Končni rezultati kažejo, da je, v primerjavi z drugimi, najvišje uvrščena metoda sinteze katalizatorja $\mathrm{Ni}-\mathrm{Pd} / \mathrm{Al}_{2} \mathrm{O}_{3}$

Ključne besede: katalizator, večkriterijska analiza, $\mathrm{Ni}-\mathrm{Pd} / \mathrm{Al}_{2} \mathrm{O}_{3}$, keramična pena, metoda aerosola

\section{INTRODUCTION}

While metal-processing technologies can have significant impact on human health, the synthesis of metal/ ceramic catalysts is conducted in a laboratory environment with a small risk on human health. ${ }^{1}$ Composite metal/ceramic catalysts are used in a wide range of heterogeneous catalytic processes, including reforming of hydrocarbons. Hydrocarbons are reformed in order to obtain $\mathrm{H}_{2}$ or a synthesis gas $\left(\mathrm{CO}+\mathrm{H}_{2}\right)$, which are highly efficient energy sources. ${ }^{2,3}$ The most common catalysts for this purpose are based on the $\mathrm{Ni} / \mathrm{Al}_{2} \mathrm{O}_{3}$ system. ${ }^{4,5}$ Despite high catalytic properties of noble-metal-based catalysts, their application is not economically favorable in industrial conditions. ${ }^{6,7} \mathrm{Ni}$ is an effective alternative for noble metals due to its low price, good catalytic activity and selectivity. In order to prevent a deactivation of active Ni particles, a low amount of an activity modifier, such as $0.1 \%$ of mass fractions of $\mathrm{Pd}$, is added. ${ }^{2,3}$
Conventional thermochemical methods for the $\mathrm{Ni} / \mathrm{Al}_{2} \mathrm{O}_{3}$ catalyst synthesis are impregnation, precipitation, coprecipitation and others. Oxide precursors for $\mathrm{Ni}$ that are supported by an $\mathrm{Al}_{2} \mathrm{O}_{3}$ powder are obtained from aqueous solutions of nickel salts and calcination in air. Also, both $\mathrm{Al}_{2} \mathrm{O}_{3}$ and oxide precursors for $\mathrm{Ni}$ can be prepared from the aqueous solutions of the corresponding metal salts. Calcination is carried out to form mixed oxides. Catalysts are then obtained with a hydrogen reduction and they are usually in the form of a powder. During the calcination procedure, undesirable and hardly reducible $\mathrm{NiAl}_{2} \mathrm{O}_{4}$ is commonly formed. In order to reduce this phase to $\mathrm{Ni}$, high reduction temperatures are required. ${ }^{4,8,9}$

There are novel methods for the catalyst synthesis, which include aerosol generation in order to form the precursors for active metals. In a previous research ${ }^{10}$, authors synthesized a monolithic $\mathrm{Ni}-\mathrm{Pd} / \mathrm{Al}_{2} \mathrm{O}_{3}$ catalyst supported by a $\mathrm{Al}_{2} \mathrm{O}_{3}$-based foam, using a novel method. The foam was prepared according to the previously 
presented procedure ${ }^{11}$ and then impregnated with ultrasonically generated aerosols of chlorides of $\mathrm{Ni}$ and $\mathrm{Pd}$. The calcination step was eliminated and the catalyst was reduced at a very low temperature, which allowed a simplification of the synthesis process and energy savings. The obtained catalyst was intended for dry methane reforming, where the synthesis gas is produced from $\mathrm{CH}_{4}$ and $\mathrm{CO}_{2} \cdot{ }^{10,12}$

Considering the work of the previous authors on the catalyst-synthesis methods, it can be concluded that none of the studies compared the catalyst-synthesis methods using a multi-criteria analysis. In this research, the novel synthesis method for the Ni-Pd/ $\mathrm{Al}_{2} \mathrm{O}_{3}$ catalyst is compared with the other Ni-based catalyst-synthesis methods using three multi-criteria analysis methods.

\section{MATERIALS AND METHODS}

Parameters (criteria) for assessing the catalyst-synthesis methods are:

Pl - Preparation method [-], expressed with a five-point scale. Impregnation is carried out by soaking the $\mathrm{Al}_{2} \mathrm{O}_{3}$ powder in a $\mathrm{Ni}\left(\mathrm{NO}_{3}\right)_{2}$ aqueous solution. With respect to the precipitation, the $\mathrm{Al}_{2} \mathrm{O}_{3}$ powder is immersed into the $\mathrm{Ni}\left(\mathrm{NO}_{3}\right)_{2}$ solution and a precipitation agent is added. Coprecipitation involves mixing the $\mathrm{Al}\left(\mathrm{NO}_{3}\right)_{3}$ solution (this salt is the precursor for $\mathrm{Al}_{2} \mathrm{O}_{3}$ ) and the $\mathrm{Ni}\left(\mathrm{NO}_{3}\right)_{2}$ solution, and then the precipitation agent is added.

P2 - Addition of the precipitation agent during the preparation [-], expressed with a two-point scale: without the addition -0 points, with the addition -1 point. Impregnation is used to deposit $\mathrm{Ni}$ ions to the $\mathrm{Al}_{2} \mathrm{O}_{3}$ surface. During the precipitation, the initial precursor for $\mathrm{Ni}$ is deposited into $\mathrm{Al}_{2} \mathrm{O}_{3}$ from the salt solution, by increasing its $\mathrm{pH}$ value with the precipitation agent. During the coprecipitation, the initial precursors for both $\mathrm{Ni}$ and $\mathrm{Al}_{2} \mathrm{O}_{3}$ are formed by increasing the $\mathrm{pH}$ value of the mixed salt solution.

$P 3$ - Forming and mixing the precursors $[K h]$, expressed by temperature $(\mathrm{K}) \times$ time $(\mathrm{h})$. The conventional thermochemical routes require a long time. The mixing of appropriate solutions with the $\mathrm{Al}_{2} \mathrm{O}_{3}$ powder during the impregnation and precipitation is usually performed at $293 \mathrm{~K}$ for $24 \mathrm{~h}$. During the coprecipitation, solutions are stirred between $313-358 \mathrm{~K}$ for $1-10 \mathrm{~h}$.

P4 - Filtration [-], expressed with a five-point scale. The solid deposit and the liquid phase are separated with filtration. After the impregnation, the deposit is only filtered and dried in an oven. However, after the precipitation and coprecipitation, the deposit is first filtered, dried and rinsed, usually with distilled water. Then, the drying procedure is repeated.

P5 - Drying procedure $[K h]$, expressed with temperature $(\mathrm{K}) \times$ time $(\mathrm{h})$. The drying of the solid deposit is carried out between $353-383 \mathrm{~K}$ for $10 \mathrm{~h}$.
P6 - Calcination parameters $[K h]$, expressed with temperature $(\mathrm{K}) \times$ time $(\mathrm{h})$. Dried deposits are calcined in air atmosphere, commonly between 873-973 K for 3-6 h, to prepare mixed oxides.

P7 - Reduction parameters $[K h]$, expressed with temperature $(\mathrm{K}) \times$ time $(\mathrm{h})$. To activate the catalysts, mixed oxides are reduced by $\mathrm{H}_{2}$, usually between 873-973 K for 1-3 h. Metallic Ni is obtained from an oxide precursor and $\mathrm{Al}_{2} \mathrm{O}_{3}$ remains as the oxide.

$\mathrm{P} 8$ - Presence of $\mathrm{NiAl}_{2} \mathrm{O}_{4}$ [-], expressed with a two-point scale: not present -0 points, present -1 point. The $\mathrm{NiAl}_{2} \mathrm{O}_{4}$ spinel phase, which occurs during the calcination, is highly undesirable due to a low reducibility. Its presence causes a lower amount of the active metallic $\mathrm{Ni}$ and lower catalyst performances.

The considered catalyst-synthesis methods are:

$\mathrm{CSMI}-\mathrm{Ni} / \mathrm{Al}_{2} \mathrm{O}_{3}, 15 \% \mathrm{Ni}$ - impregnation - Powder $\gamma-\mathrm{Al}_{2} \mathrm{O}_{3}$ and aqueous $\mathrm{Ni}\left(\mathrm{NO}_{3}\right)_{2}$ solution were stirred at room temperature for $24 \mathrm{~h}$ and filtered. The deposit was dried at $383 \mathrm{~K}$ for $10 \mathrm{~h}$ and calcined at $873 \mathrm{~K}$ for $3 \mathrm{~h}$. Reduction was performed at $873 \mathrm{~K}$ for $2 \mathrm{~h}^{4}$

$\mathrm{CSM} 2$ - $\mathrm{Ni}_{\mathrm{A}} \mathrm{Al}_{2} \mathrm{O}_{3}, 15 \% \mathrm{Ni}$ - precipitation - The $\mathrm{Ni}\left(\mathrm{NO}_{3}\right)_{2}$ solution was added to the solution of the precipitating agent $\left(\mathrm{Na}_{2} \mathrm{CO}_{3}\right)$, which contained the $\gamma-\mathrm{Al}_{2} \mathrm{O}_{3}$ powder. After stirring the mixture for $24 \mathrm{~h}$, the deposit was filtered, dried at $353 \mathrm{~K}$ for $10 \mathrm{~h}$, then rinsed with distilled water and dried again at $383 \mathrm{~K}$ for $10 \mathrm{~h}$. The obtained deposit was calcined at $873 \mathrm{~K}$ for $3 \mathrm{~h}$ and reduced at $873 \mathrm{~K}$ for $2 \mathrm{~h}^{4}{ }^{4}$

$\mathrm{CSM} 3$ - $\mathrm{Ni} / \mathrm{Al}_{2} \mathrm{O}_{3}, 15 \% \mathrm{Ni}$ - coprecipitation - A solution of $\mathrm{Ni}\left(\mathrm{NO}_{3}\right)_{2}$ and $\mathrm{Al}\left(\mathrm{NO}_{3}\right)_{3}$ was added drop-wise into the $\mathrm{Na}_{2} \mathrm{CO}_{3}$ solution. After constant stirring at $313 \mathrm{~K}$, the resulting deposit was additionally stirred for $1 \mathrm{~h}$. The filtered deposit was dried at $353 \mathrm{~K}$ for $10 \mathrm{~h}$, rinsed with distilled water and then dried at $383 \mathrm{~K}$ for $10 \mathrm{~h}$. Calcination parameters were $873 \mathrm{~K}$ and $3 \mathrm{~h}$. Reduction was performed at $873 \mathrm{~K}$ for $2 \mathrm{~h} .^{4}$

$\mathrm{CSM} 4-\mathrm{Ni} / \mathrm{Al}_{2} \mathrm{O}_{3}, 20 \% \mathrm{Ni}$ - sequential precipitation - Separate solutions of $\mathrm{Ni}\left(\mathrm{NO}_{3}\right)_{2}$ and $\mathrm{Al}\left(\mathrm{NO}_{3}\right)_{3}$ were prepared. First, a $\mathrm{NH}_{4} \mathrm{OH}$ solution was added to the $\mathrm{Al}\left(\mathrm{NO}_{3}\right)_{3}$ solution in order to form a white deposit. Then, the $\mathrm{NH}_{4} \mathrm{OH}$ and $\mathrm{Ni}\left(\mathrm{NO}_{3}\right)_{2}$ solutions were slowly added to the solution with the white deposit until a blue deposit was obtained. The resulting product was kept at $293 \mathrm{~K}$ for $24 \mathrm{~h}$. The separation of the deposit from the liquid was followed by rinsing with ethanol, drying at $373 \mathrm{~K}$ for $10 \mathrm{~h}$, calcination at $973 \mathrm{~K}$ for $5 \mathrm{~h}$ and reduction at $973 \mathrm{~K}$ for 3 h. $^{13}$

$\mathrm{CSM} 5-\mathrm{Ni} / \mathrm{Al}_{2} \mathrm{O}_{3}, 50 \% \mathrm{Ni}$ - coprecipitation Dissolved $\mathrm{Ni}\left(\mathrm{NO}_{3}\right)_{2}$ and $\mathrm{Al}\left(\mathrm{NO}_{3}\right)_{3}$ were mixed with urea (the precipitation agent) and stirred at $358 \mathrm{~K}$ for $10 \mathrm{~h}$. The deposit was washed, filtered and dried at $383 \mathrm{~K}$ for $10 \mathrm{~h}$. Calcination was carried out at $923 \mathrm{~K}$ for $6 \mathrm{~h}$ and the catalyst was reduced at $973 \mathrm{~K}$ for $1 \mathrm{~h}^{9}$

$\mathrm{CSM6}$ - $\mathrm{Ni} / \mathrm{Al}_{2} \mathrm{O}_{3}, 50 \% \mathrm{Ni}$ - coprecipitation - This catalyst was prepared according to the CSM5 procedure, 
Table 1: Performance matrix: properties of synthesis methods for Ni-based catalysts

Tabela 1: Matrika uspešnosti: lastnosti metod sinteze katalizatorjev na osnovi Ni

\begin{tabular}{|c|c|c|c|c|c|c|c|c|c|c|c|c|c|c|}
\hline \multirow{2}{*}{$\begin{array}{c}\text { Parameter/ } \\
\text { catalyst }\end{array}$} & \multicolumn{4}{|c|}{$\mathrm{P} 1$} & \multirow{2}{*}{$\mathrm{P} 2$} & \multirow{2}{*}{ P3 } & \multicolumn{4}{|c|}{ P4 } & \multirow{2}{*}{ P5 } & \multirow{2}{*}{ P6 } & \multirow{2}{*}{ P7 } & \multirow{2}{*}{ P8 } \\
\hline & DM1 & DM2 & DM3 & Sum & & & DM1 & DM2 & DM3 & Sum & & & & \\
\hline CSM1 & 3 & 2 & 3 & 8 & 0 & 7032 & 3 & 3 & 3 & 9 & 3830 & 2619 & 1746 & 1 \\
\hline CSM2 & 4 & 3 & 5 & 12 & 1 & 7032 & 1 & 1 & 2 & 4 & 7360 & 2619 & 1746 & 0 \\
\hline CSM3 & 2 & 1 & 1 & 4 & 1 & 313 & 1 & 1 & 2 & 4 & 7360 & 2619 & 1746 & 1 \\
\hline CSM4 & 4 & 3 & 5 & 12 & 1 & 7032 & 3 & 2 & 3 & 8 & 3730 & 4865 & 2919 & 1 \\
\hline CSM5 & 2 & 1 & 1 & 4 & 1 & 3580 & 3 & 2 & 3 & 8 & 3830 & 5538 & 973 & 0 \\
\hline CSM6 & 2 & 1 & 1 & 4 & 1 & 3580 & 3 & 2 & 3 & 8 & 3830 & 5538 & 973 & 1 \\
\hline CSM7 & 3 & 5 & 4 & 12 & 0 & 473 & 5 & 5 & 5 & 15 & 473 & 0 & 799,5 & 0 \\
\hline
\end{tabular}

with the same calcination and reduction conditions. $\mathrm{K}_{2} \mathrm{CO}_{3}$ was used as the precipitation agent. ${ }^{9}$

$\mathrm{CSM} 7$ - Ni-Pd/Al${ }_{2} \mathrm{O}_{3}, 20 \% \mathrm{Ni}, 0.1 \% \mathrm{Pd}-$ The authors synthesized this catalyst with a novel method, that involved an impregnation of $\mathrm{Al}_{2} \mathrm{O}_{3}$-based foams with an ultrasonically generated aerosol of chlorides of $\mathrm{Ni}$ and Pd. Impregnation was performed for $1 \mathrm{~h}$ at $473 \mathrm{~K}$. Afterwards, the chlorides deposited onto the foam were dried at $473 \mathrm{~K}$ for $1 \mathrm{~h}$. Calcination was eliminated and the reduction of the chlorides was carried out for $1.5 \mathrm{~h}$ at a very low temperature $-533 \mathrm{~K}$. The chlorides were nearly completely reduced and their reduction degree was 98.2 $\%$ of mass fractions. ${ }^{10}$

The performance matrix, the properties of the catalysts based on system $\mathrm{Ni} / \mathrm{Al}_{2} \mathrm{O}_{3}$ synthesized with different methods, is given in Table 1. Parameters P1 and P4 represent the decision makers' preference according to their experience, expressed with points in the range of one to five. The final parameter values for $\mathrm{P} 1$ and $\mathrm{P} 4$ are obtained as the sum of all decision makers' preferences. The five-point rating scale was used for evaluating parameters P1 and P4, where one point represents the least desirable and five points represent the most desirable solution.

SAW (Simple Additive Weighting), TOPSIS (Technique for Order Preference by Similarity to Ideal Solution) and PROMETHEE II (Preference Ranking Organization METHod for Enrichment Evaluation) methods were used for a multi-criteria assessment of the catalyst-synthesis methods.

SAW is a simple method that usually provides results similar to the ones obtained with more complex methods. ${ }^{14}$ After assigning the parameter weighting factors $w_{j}$ using Equation (1) for every alternative, the total value $S_{i}$ is calculated, where the best alternative has the largest $S_{i}$ value:

$$
\begin{aligned}
& S_{i}=\sum_{j=1}^{m} w_{j} b_{i j} ; i=1,2, \ldots, n \\
& \sum_{j=1}^{m} w_{j}=1 ; \quad 0 \leq w_{j} \leq 1
\end{aligned}
$$

Normalized performance-matrix elements $b_{i j}$ are calculated with Equations (2) and (3):

$$
b_{i j}=\frac{a_{i j}-a_{j}^{-}}{a_{j}^{*}-a_{j}^{-}}
$$

for the parameters that have to be maximized,

$$
b_{i j}=1-\frac{a_{i j}-a_{j}^{-}}{a_{j}^{*}-a_{j}^{-}}
$$

for the parameters that have to be minimized,

where: $S_{i}$ - rating of $i$ th-alternative (alternative rank), $w_{j}$ - parameter weighting factor, $b_{i j}$ - normalized matrix element, $a_{i j}$ - performance matrix element, $a_{j} *-j$-parameter ideal solution (the maximum value), $a_{j}^{-}-j$-parameter anti-ideal solution (the minimum value), $n-$ number of alternatives, $m$ - number of parameters.

The basic principle of the TOPSIS method is that the chosen alternative should have the shortest distance from the ideal solution and the farthest distance from the negative-ideal solution. ${ }^{15}$ The TOPSIS procedure consists of six steps:

1. Normalization of the performance matrix. The performance matrix $X_{(n, m)}$, where each matrix row corresponds to one alternative, and each column to a single criterion, is normalized with the following Equation (4):

$$
r_{i j}=\frac{x_{i j}}{\sqrt{\sum_{i=1}^{n} x_{i j}^{2}}} i=1, \ldots, n, j=1, \ldots, m
$$

2. Calculation of the weighted normalized performance matrix. Weighted normalized performance-matrix values $v_{i j}$ are calculated in Equation (5) as:

$$
v_{i j}=w_{j} r_{i j}
$$

where $w_{j}$ is the parameter weight and $\Sigma w_{j}=1$.

3. Determining the ideal and anti-ideal solutions. The ideal solution $A^{+}$and anti-ideal solution $A^{-}$are determined with Equations (6) and (7):

$$
\begin{aligned}
& A^{+}=\left\{\left(\max v_{i j} \mid j \dot{\varepsilon} G\right),\left(\min v_{i j} \mid j \dot{\varepsilon} G^{\prime}\right), i=1, \ldots, n\right\}= \\
& =\left\{v_{1}^{+}, v_{2}^{+}, \ldots, v_{m}^{+}\right\} \\
& A^{-}=\left\{\left(\min v_{i j} \mid j \dot{\varepsilon} G\right),\left(\max v_{i j} \mid j \dot{\varepsilon} G^{\prime}\right), i=1, \ldots, n\right\}= \\
& =\left\{v_{1}^{-}, v_{2}^{-}, \ldots, v_{m}^{-}\right\}
\end{aligned}
$$

where: 
$G=\{j=1,2, \ldots, m \mid j$ parameters that have to be maximized $\}$

$G^{\prime}=\{j=1,2, \ldots, m \mid j$ parameters that have to be minimized $\}$

4. Calculations of the distances from the ideal and anti-ideal solutions.

$$
\begin{gathered}
D_{i}^{+}=\sqrt{\sum_{j=1}^{m}\left(v_{i j}-v_{j}^{+}\right)^{2}}, i=1, \ldots, n \\
D_{i}^{-}=\sqrt{\sum_{j=1}^{m}\left(v_{i j}-v_{j}^{-}\right)^{2}}, i=1, \ldots, n
\end{gathered}
$$

5. Calculation of relative closeness $(R C)$ to ideal solution.

$$
R C_{i}^{+}=\frac{D_{i}^{-}}{D_{i}^{+}+D_{i}^{-}}, i=1, \ldots, n
$$

where $0 \leq R C_{i}^{+} \leq 1$.

6. Ranking of alternatives. Alternatives are ranked by descending values of $\mathrm{RC}_{i}^{+}$.

The PROMETHEE I method provides a partial ranking, while PROMETHEE II provides a complete ranking of alternatives. ${ }^{16,17}$ The main feature of the PROMETHEE method is the fact that for each parameter, the decision maker assigns one of the six predefined preference functions provided in ${ }^{16,17}$. Only the two preference functions, which are used in this paper, are described here. The usual preference function (Equations (11) and (12)) is used for qualitative criteria (P1 and P4), while a $\mathrm{V}$-shape preference function (Equations (13) and (14)) is used for quantitative criteria (P2, P3, P5, P6, P7, and P8):

$$
P_{\text {usual }}(a, b)= \begin{cases}0, & d(a, b) \leq 0 \\ 1, & d(a, b)>0\end{cases}
$$

parameters that have to be maximized

$$
P_{\text {usual }}(a, b)= \begin{cases}0, & d(a, b)>0 \\ 1, & d(a, b) \leq 0\end{cases}
$$

parameters that have to be minimized

$$
P_{\mathrm{V} \text {-shape }}(a, b)=\left\{\begin{array}{cc}
\frac{|d(a, b)|}{p}, & d(a, b) \leq p \\
1, & d(a, b)>p
\end{array}\right.
$$

parameters that have to be maximized

$$
P_{\mathrm{V} \text {-shape }}(a, b)=\left\{\begin{array}{cc}
\frac{|d(a, b)|}{p}, & d(a, b)>p \\
1, & d(a, b) \leq p
\end{array}\right.
$$

parameters that have to be minimized

where $d_{j}(a, b)$ is a deviation in the assessment of alternative $a$ over alternative $b$ for each parameter, and $p$ is the preference threshold.

PROMETHEE II can be calculated through the following five steps:

1. Defining the deviations according to pairwise comparisons,

$$
d_{j}(a, b)=g_{j}(a)-g_{j}(b)
$$

where $d_{j}(a, b)$ is the deviation in the assessment of alternative $a$ over alternative $b$ for each parameter.

2. Applying the preference functions,

$$
P_{j}(a, b)=F_{j}\left\lfloor d_{j}(a, b)\right\rfloor ; j=1,2, \ldots, m
$$

where $P_{j}(a, b)$ is the preference of alternative $a$ over alternative $b$ for each parameter, as function $d_{j}(a, b)$.

3. Calculating the total preference index,

$$
\forall a, b \in A, \pi(a, b)=\sum_{j=1}^{m} P_{j}(a, b) w_{j}
$$

where $\pi_{j}(a, b)$, from $a$ to $b$ (from 0 to 1 ), is defined with the weighted sum $P_{j}(a, b)$ for each $j$-parameter, and $w_{j}$ is the weighting factor of $j$-parameter.

4. Calculating the positive $\left(\phi^{+}\right)$and negative flows $\left(\phi^{-}\right)$- PROMETHEE I partial ranking,

$$
\begin{aligned}
\phi^{+}(a) & =\frac{1}{n-1} \sum_{x \in A} \pi(a, x) \\
\phi^{-}(a) & =\frac{1}{n-1} \sum_{x \in A} \pi(x, a)
\end{aligned}
$$

5. Calculating the net flow $(\phi)-$ PROMETHEE II

\begin{tabular}{|c|c|c|c|c|c|c|c|c|}
\hline Parameter preferences & $\mathrm{P} 1$ & $\mathrm{P} 2$ & P3 & $\mathrm{P} 4$ & P5 & P6 & P7 & P8 \\
\hline Parameter weight (DM1) & 1 & 2 & 3 & 2 & 6 & 9 & 7 & 6 \\
\hline Parameter weight (DM2) & 2 & 2 & 6 & 2 & 8 & 10 & 9 & 6 \\
\hline Parameter weight (DM3) & 1 & 1 & 5 & 1 & 5 & 9 & 6 & 8 \\
\hline Final parameter weight & 0.0333 & 0.0426 & 0.1204 & 0.0426 & 0.1611 & 0.2407 & 0.1870 & 0.1741 \\
\hline Parameter type & Max & Min & Min & Max & Min & Min & Min & Min \\
\hline PROMETHEE Pref. function & Usual & Usual & V-shape & Usual & V-shape & V-shape & V-shape & Usual \\
\hline PROMETHEE Pref. threshold & - & - & 6000 & - & 6000 & 5000 & 2000 & - \\
\hline
\end{tabular}
complete ranking,

$$
\phi(a)=\phi^{+}(a)-\phi^{-}(a)
$$

Parameter preferences of the decision makers (parameter weight, type, PROMETHEE preference function and preference threshold) for MCA are provided in Table 2. Parameter weighting factors (in this case DM1, DM2 and DM3) are assigned by the decision makers, who are experts in field of Nickel-based catalysts, for

Table 2: Parameter preferences

Tabela 2: Nastavitve parametrov 
each parameter on a ten-point scale. The final, aggregated weighting factor is calculated with the following Equation (21):

$$
w_{F, j}=\frac{1}{k} \sum_{k=1}^{l} \frac{w_{D M, k, j}}{\sum_{j=1}^{m} w_{D M, k, j}}, j=1, \ldots, m ; k=1, \ldots, l
$$

where $w_{F, j}$ is the final weighting factor, $w_{D M, k}$ is the weighting factor of $k$-th decision maker, $m$ is the number of parameters, $l$ is the number of decision makers.

\section{RESULTS AND DISCUSSION}

According to the decision makers' preferences (Table 2), parameters P6, P7, P5, and P8 were considered as the most important. The qualitative parameters, obtained on the basis of the decision makers' preferences on the five-point scale, P1 and P4, were considered as the least important by the decision makers. After the decision makers expressed their preferences about the parameters for the catalyst-synthesis methods from Table 2, three MCA methods (SAW, TOPSIS, and PROMETHEE II) were applied in order to obtain the results shown in Figures 1 and 2.

The normalization results of the TOPSIS method (vector normalization), shown in Figure 1, show the "default scenario" without the decision makers' preferences. From Figure 1 it is clear that catalyst $\mathrm{Ni}-\mathrm{Pd} / \mathrm{Al}_{2} \mathrm{O}_{3}$ (CSM7) stands out from the rest. The normalization results for catalyst $\mathrm{Ni}-\mathrm{Pd} / \mathrm{Al}_{2} \mathrm{O}_{3}$ are affected by the fact that in the performance matrix (Table 1) catalyst $\mathrm{Ni}-\mathrm{Pd} / \mathrm{Al}_{2} \mathrm{O}_{3}$ has the best values (ideal solution) for parameters P2, P4, P5, P6 and P7.

As in the normalization results, the results for all three MCA methods (SAW, TOPSIS, PROMETHEE II) shown in Figure 2, indicate that the best ranked catalyst is $\mathrm{Ni}-\mathrm{Pd} / \mathrm{Al}_{2} \mathrm{O}_{3}$. When the decision makers' weighting factors are included in the three MCA methods (Figure 2), $\mathrm{Ni}-\mathrm{Pd} / \mathrm{Al}_{2} \mathrm{O}_{3}$ is even more distinguished from the other catalysts than in the normalization results (Figure

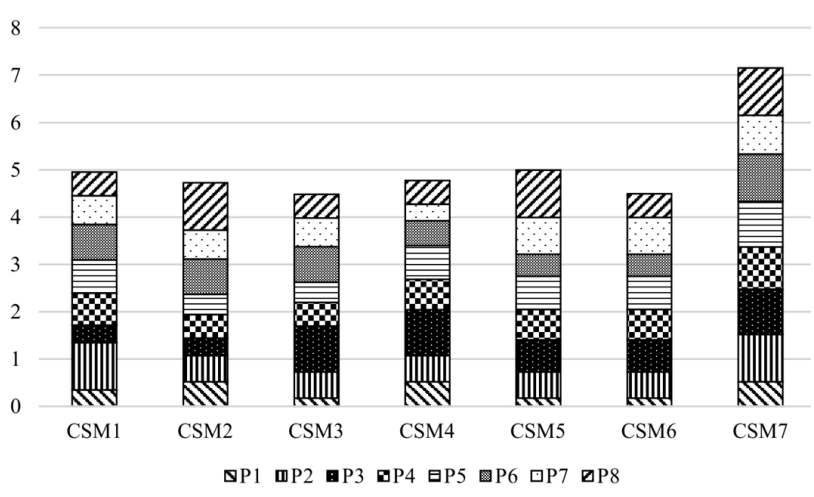

Figure 1: Normalization results (vector normalization in TOPSIS) Slika 1: Rezultati normalizacije (vektorska normalizacija TOPSIS)

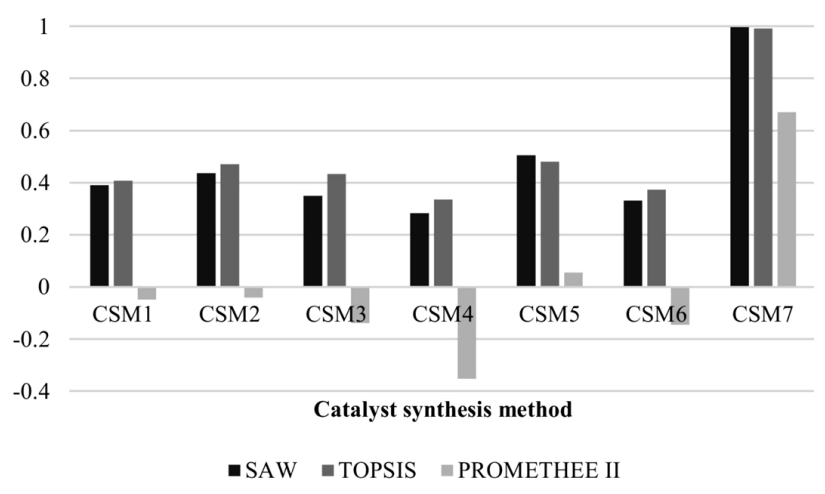

Figure 2: Ranking of catalyst-synthesis methods Slika 2: Razvrstitev metod sinteze katalizatorja

1). On the other hand, catalyst-synthesis methods CSM3, CSM4 and CSM6 are ranked as the poorest.

\section{CONCLUSION}

The best ranked catalyst-synthesis method is the novel method for obtaining the $\mathrm{Ni}-\mathrm{Pd} / \mathrm{Al}_{2} \mathrm{O}_{3}$ catalyst according to the normalization results (Figure 1) and the results for all three MCA methods (SAW, TOPSIS, PROMETHEE II) (Figure 2). For a multi-criteria analysis, it is common that the results of different methods differ to some extent, as in this case. However, all three methods indicated the $\mathrm{Ni}-\mathrm{Pd} / \mathrm{Al}_{2} \mathrm{O}_{3}$ catalyst as the best solution, which is a strong proof that the novel catalyst-synthesis method stands out from the rest.

The Ni-Pd/ $/ \mathrm{Al}_{2} \mathrm{O}_{3}$ catalyst was synthesized with a novel method, which includes impregnation of $\mathrm{Al}_{2} \mathrm{O}_{3}$ based foams with an ultrasonically generated aerosol of metal chlorides. The method enabled elimination of the calcination step and the chloride precursors were almost completely reduced (98.2\% of mass fractions) at a very low temperature of $533 \mathrm{~K}$. This may provide economic and technological benefits in the catalyst production process.

Future research will be focused on the life-cycle analysis of the synthesis method for the $\mathrm{Ni}-\mathrm{Pd} / \mathrm{Al}_{2} \mathrm{O}_{3}$ catalyst, where the consumption of natural resources and energy sources in the production phase will be analyzed. Assessment results for the life-cycle impact will provide more information about the synthesis method for the $\mathrm{Ni}-\mathrm{Pd} / \mathrm{Al}_{2} \mathrm{O}_{3}$ catalyst and environmental impacts on impact categories such as human health, natural resources and ecosystem quality.

\section{Acknowledgement}

This research was financially supported by the Ministry of Education, Science and Technological Development of the Republic of Serbia and it is a result of projects Nos. 34033 and 35020. 


\section{REFERENCES}

${ }^{1}$ M. Ilić, I. Budak, B. Kosec, A. Nagode, J. Hodolič, The Analysis of Particles Emission During the Process of Grinding of Steel EN 90MnV8, Metalurgija, 53 (2014), 189-192

${ }^{2}$ A. N. Fatsikostas, D. I. Kondarides, X. E. Verykios, Production of hydrogen for fuel cells by reformation of biomass-derived ethanol, Catalysis Today, 75 (2002), 145-155, doi:10.1016/S0920-5861(02) 00057-3

${ }^{3}$ L. P. R. Profeti, J. A. C. Dias, J. M. Assaf, E. M. Assaf, Hydrogen production by steam reforming of ethanol over Ni-based catalysts promoted with noble metals, Journal of Power Sources, 190 (2009), 525-533, doi:10.1016/j.jpowsour.2008.12.104

${ }^{4}$ A. J. Akande, R. O. Idem, A. K. Dalai, Synthesis, characterization and performance evaluation of $\mathrm{Ni} / \mathrm{Al}_{2} \mathrm{O}_{3}$ catalysts for reforming of crude ethanol for hydrogen production, Applied Catalysis A: General, 287 (2005), 159-175, doi:10.1016/j.apcata.2005.03.046

${ }^{5}$ A. J. Zhang, A. M. Zhu, J. Guo, Y. Xu, C. Shi, Conversion of greenhouse gases into syngas via combined effects of discharge activation and catalysis, Chemical Engineering Journal, 156 (2010), 601-606, doi:10.1016/j.cej.2009.04.069

${ }^{6}$ M. A. Goula, S. K. Kontou, P. E. Tsiakaras, Hydrogen production by ethanol steam reforming over a commercial $\mathrm{Pd} / \gamma-\mathrm{Al} 2 \mathrm{O} 3$ catalyst, Applied Catalysis B: Environmental, 49 (2004), 135-144, doi:10.1016/j.apcatb.2003.12.001

${ }^{7}$ D. K. Liguras, D. I. Kondarides, X. E. Verykios, Production of hydrogen for fuel cells by steam reforming of ethanol over supported noble metal catalysts, Applied Catalysis B: Environmental, 43 (2003), 345-354, doi:10.1016/S0926-3373(02)00327-2

${ }^{8}$ J. Juan-Juan, M. C. Roman-Martinez, M. J. Illan-Gomez, Nickel catalyst activation in the carbon dioxide reforming of methane: Effect of pretreatments, Applied Catalysis A: General, 355 (2009), 27-32, doi:10.1016/j.apcata.2008.10.058

${ }^{9}$ Y. Jung, W. Yoon, Y. Seo, Y. Rhee, The effect of precipitants on $\mathrm{Ni}-\mathrm{A} 12 \mathrm{O} 3$ catalysts prepared by a co-precipitation method for internal reforming in molten carbonate fuel cells, Catalysis Communications, 26 (2012), 103-111, doi:10.1016/j.catcom.2012. 04.029

${ }^{10}$ V. Nikolić, Ž. Kamberović, Z. Anđić, M. Korać, M. Sokić, V. Maksimović, Influences of synthesis methods and modifier addition on the properties of Ni-based catalysts supported on reticulated ceramic foams, International Journal of Minerals, Metallurgy, and Materials, 21 (2014), 806-812, doi:10.1007/s12613-014-0974-x

${ }^{11}$ V. Nikolić, Ž. Kamberović, Z. Anđić, M. Korać, M. Sokić, Synthesis of $\alpha-\mathrm{Al}_{2} \mathrm{O}_{3}$ based foams with improved properties as catalyst carriers, Mater. Tehnol., 48 (2014), 45-50

${ }^{12}$ V. Nikolić, Ž. Kamberović, M. Korać, Z. Anđić, M. Sokić, A. Tomović, Ni-Pd/ $\mathrm{Al}_{2} \mathrm{O}_{3}$ catalyst supported on reticulated ceramic foam for dry methane reforming, Metallurgical and Materials Engineering, 21 (2015), 57-63

${ }^{13}$ J. G. Seo, M. H. Youn, D. R. Park, I. Nam, I. K. Song, Hydrogen production by steam reforming of liquefied natural gas (LNG) over $\mathrm{Ni}-\mathrm{Al}_{2} \mathrm{O}_{3}$ catalysts prepared by a sequential precipitation method: Effect of precipitation agent, International Journal of Hydrogen Energy, 34 (2009), 8053-8060, doi:10.1016/j.ijhydene.2009.08.020

${ }^{14}$ E. Triantaphyllou, Multi-Criteria Decision Making: A Comparative Study, Kluwer Academic Publishers (Springer), Dordrecht, The Netherlands 2000, 320

${ }^{15}$ C. L. Hwang, K. Yoon, Multiple Attribute Decision Making, Lecture Notes in Economics and Mathematical Systems 186, SpringerVerlag, Berlin 1981

${ }^{16}$ J. P. Brans, Lingenierie de la decision, Elaboration dinstruments daide a la decision, Methode PROMETHEE, Laide a la Decision: Nature, Instruments et Perspectives d'Avenir, Presses de l'Université Laval, Québec, Canada, 1982, 183-214

${ }^{17}$ J. P. Brans, B. Mareschal, The PROMETHEE methods for MCDM, the PROMCALC, GAIA and Bankadviser Software, Working Paper ST001224, Vrije Universiteit, Brussel 1989 